\title{
Effect of Supplementing Butyric Acid on Growth Performance and Carcass Quality Traits in Broiler
}

\author{
Kartik Tomar $^{1 *}$, Raj Kumar ${ }^{1}$, Debashis Roy ${ }^{2 *}$, Nazim Ali ${ }^{1}$, S.P. Yadav ${ }^{1}$, D.S. Sahu ${ }^{1}$, Ajit Kumar ${ }^{2}$, \\ Mpho Nametso Moilwa ${ }^{1}$ and Manoj Kumar Bansala ${ }^{1}$ \\ ${ }^{1}$ Department of Animal Husbandry, College of Agriculture, Sardar Vallabhbhai Patel University of Agriculture E Technology, \\ Meerut, Uttar Pradesh, INDIA \\ ${ }^{2}$ Department of Animal Nutrition, College of Veterinary and Animal Science, Sardar Vallabhbhai Patel University of Agriculture \\ E Technology, Meerut, Uttar Pradesh, INDIA
}

"Corresponding author: K Tomar; E-mail: kktomar996@gmail.com

Received: 08 Oct., 2020

Revised: 10 Nov., 2020

Accepted: 18 Nov., 2020

\begin{abstract}
The effect of supplementing different levels of butyric acid on the growth performance and carcass characteristics traits on broiler chickens was observed in the present experiment. One hundred and eighty day-old broiler chicks (Cobb 400) were randomly assigned to four dietary treatments (Control, $0.5 \%, 1 \%$ and $1.5 \%$ of Butyric acid). Each treatment was replicated three times with 15 birds/replicate. Growth performance e.g. feed intake, body weight gain, feed conversion ratio were observed. Carcass characteristics traits and development of digestive organs were observed by sacrificing four birds per group at the end of the trial. Weekly body weight gain was found to increase significantly in all supplemented groups on $6^{\text {th }}$ week. Overall body weight gain was found higher in $\mathrm{T}_{3}$ group than other groups. The eviscerated yield (gm) and eviscerated yield (\%) were represented to highest in $\mathrm{T}_{4}$ supplemented group whereas ready to cook yield (gm) and ready to cook yield (\%) is also highest in $\mathrm{T}_{4}$ supplemented group than control. Digestive organ except proventricular (\%) and cecal length (\%) were found to differ significantly in all experimental groups. Small intestine (\%), small intestine length (\%) and large intestine (\%) were observed to highest in $\mathrm{T}_{4}$ supplemented group than control. The results indicated that supplementation of butyric acid up to the level of $1.5 \%$ of feed improves the growth performance and feed utilization in commercial broiler without having any adverse effect on carcass quality traits in commercial broiler.
\end{abstract}

\section{HIGHLIGHTS}

(0 Butyric acid supplementation on growth performance of broiler.

0 To study carcass quality of broiler after supplementation of butyris acid.

Keywords: Broiler performance, Feed consumption, Carcass traits, Butyric acid

Broiler is an important part of commercial poultry enterprise. India is the fourth largest broiler producer in the world after China, US and Brazil. The modern broiler chicken is fast growing, efficient and can rapidly fulfil the shortage of protein requirement for human consumption since it can be produced in least possible time as compared to other meat producing animals (Sarkar et al., 2008) The term organic acid refers to a broad class of compounds used in fundamental metabolic processes of the body. Organic acids are weak acids and are only partly dissociated. Most organic acids with antimicrobial activity have a $\mathrm{pKa}$ (the $\mathrm{pH}$ at which the acid is half dissociated) between 3 and 5. A wide range of organic acids with variable physical and chemical properties exists, of which many can be used as drinking water supplements or as feed additives

How to cite this article: Tomar, K., Kumar, R., Roy, D., Ali, N., Yadav, S.P., Sahu, D.S., Kumar, A., Moilwa, M.N. and Bansala, M.K. (2020). Effect of supplementing butyric acid on growth performance and carcass quality traits in broiler. J. Anim. Res., 10(6): 985-991.

Source of Support: None; Conflict of Interest: None 
(acidifiers). They are also less corrosive and may be more soluble in water (Huyghebaert et al., 2011). Organic acids have strong bacteriostatic effects and have been used as Salmonella controlling agents in feed and water supplies for poultry. Organic acids helps to maintain an optimum $\mathrm{pH}$ in the stomach, allowing correct activation and function of proteolytic enzymes and in total protein digestion in the stomach, stimulate feed consumption, inhibits the growth of pathogenic bacteria, improve protein and energy digestibility by reducing microbial competition with host nutrients and endogenous nitrogen losses. It increases pancreatic secretion and tropic effects on gastrointestinal mucosa. Butyric acid is thus known to have antimicrobial, anticatabolic and antioxidant effect together improving the lipid metabolism, mineral absorption and immune status of birds. It is also known to improve the carcass characteristics and overall performance of broiler birds. Present experiment was conducted to see the effect of supplementing different levels of butyric acid on the growth performance and carcass characteristics traits on broiler chickens.

\section{MATERIALS AND METHODS}

\section{Experimental site}

This experiment was conducted at Poultry Research and Training Center, Sardar Vallabhbhai Patel University of Agriculture \& Technology, Modipuram, Meerut-250110 (U.P.). Geographically Meerut is situated between $29^{0} 01^{\prime}$ " latitude in the north and $77^{\circ} 45^{\prime}$ " longitudes in the East.

\section{Experimental Feeds and Nutritional analysis}

The birds were given ad libitum pelleted diets and water throughout the period of the study (42 days). Standard broiler feeds for the starter (0-3 weeks) and finisher (4-6 weeks) periods as per BIS specifications (1992) were procured from market. In treatment group, the measured amount of butyric acid was supplemented at different levels in the basal diets as 0.5, 1.0 and 1.5\%. Butyric acid was purchased from local market. Samples were obtained from the starter feed and finisher feed. They were analyzed for nutrient composition viz. dry matter, crude protein, ether extract, total ash, crude fibre as per AOAC (2005). The proximate analysis viz. moisture, crude protein, crude fat, crude fibre, NFE and total ash as well as $\mathrm{Ca}$ and $\mathrm{P}$ of feed were determined as per the methods of AOAC (2005).

\section{Experimental birds, design, feeding and management}

One hundred and eighty day-old broiler chicks (Cobb 400) strain were procured and were randomly distributed into 4 treatments with 3 replications. Each replicate contained 15 chicks. Chicks were reared in electric brooder until 7 days of age. Chicks had free access to feed and water throughout and were maintained on a constant 24 hours light schedule. Experimental house and brooding pens were thoroughly cleaned, disinfected, fumigated and remain closed for a period of 15 days before the arrival of chicks. All the feeders, drinkers and other utensils were thoroughly washed and disinfected. The broilers were weighed individually every week till the end of experiment.

\section{Observations recorded}

\section{Growth parameters}

On the basis of these weights, weight gains in different groups of broilers were calculated weekly. Daily record of feed given to different groups was recorded. Left over feed was weighed weekly. The feed intake in different groups was calculated by subtracting the weight of left over feed from the weight of total feed offered within a period of time.

\section{Carcass characteristics}

Four broilers birds were selected randomly at the end of experimental period from each treatment. Live weight of all the birds were recorded in the evening and they were allowed to fast for 16 hours (overnight), however, drinking water was provided. These birds were killed in slaughter cones by severing the carotid artery and jugular veins (Halal method).Birds were allowed to bleed for four minutes until there was no blood oozing from the carcasses. Head and shanks were removed using a sharp knife which had been used to severe the jugular vein. Evisceration was carried out by making a circular incision around vent to cut open the abdominal cavity and removing all the internal organs. After the removal of heads and shanks, carcasses 
were weighed to determine their dressing percentage and manually eviscerated to determine other carcass traits. Birds of all the four treatment groups were dressed and weighed in same manner.

\section{STATISTICAL ANALYSIS}

Data obtained was subjected to analysis completely randomized design with the simple analysis of variance technique (Snedecor and Cochran, 1994) using Statistical Package for the Social Sciences (SPSS, 2011). Differences among treatments were considered to be significant when $\mathrm{P} \leq 0.05$. The experiment will be conducted in complete randomized design (CRD).

\section{RESULTS AND DISCUSSION}

\section{Nutrient and chemical composition of experimental diets}

In table 1 the analyzed chemical composition of experimental diet is presented as the proximate principles i.e. dry matter, total ash, crude protein, ether extract, crude fiber and nitrogen free extract of starter feed as well as finisher feed remains similar. The cell wall constituents i.e. NDF and ADF and $\mathrm{Ca}$ and $\mathrm{P}$ contents for starter and finisher feed is also same condition as proximate principles. The analyzed nutrient content of experimental diet were almost similar in terms of its protein and other proximate parameters. The amino acids, minerals, essential fatty acid and vitamin contents of the diets were similar to the nutrient requirement suggested by BIS specifications (1992). Ghazalah et al. (2011) reported that dietary $0.5 \%$ of either fumaric or formic acid and $0.75 \%$ of acetic or $2 \%$ citric acid improved crude protein $(\mathrm{CP})$, ether extract (EE), crude fibre (CF) and nitrogen-free extract (NFE) of broiler diets.

\section{Growth performance}

The body weight of broiler of all the four groups measured at weekly interval is presented in table 2. Body weight was found differ significantly between the groups from $2^{\text {nd }}$ to $6^{\text {th }}$ week. The highest body weight was observed in the supplemented group $\mathrm{T}_{4}$ which was followed by $\mathrm{T}_{3}$, $\mathrm{T}_{2}$ and $\mathrm{T}_{1}$ groups. Panda et al. (2009) showed that $0.4 \%$ butyrate in the diet was similar to antibiotic in maintaining body weight gain. On contrary, Aghazadeh and Tahayazdi (2012) evaluate the effect of butyric acid and wheat on the performance of broiler chickens and concluded that dietary supplementation with butyric acid had no effect on average weight gain $(A W G)$ in the starter, grower/finisher. Imran et al. (2018) determined the effect of microencapsulated butyric acid (MEBA) on growth performance in broiler and observed the improved body weight gain. Mohamed et al. (2018) found no effect of different levels of organic mixture on feed conversion ratio of broiler chickens. Islam et al. (2008) showed significant increase in body weight gain when compared with the control during 0-5 weeks of age on $0.5 \%$ citric acid (B).

Table 1:Analyzed nutrient content of experimental diet $(\mathrm{g} / \mathrm{kg}$ as $\mathrm{DM})$

\begin{tabular}{lll}
\hline \multirow{2}{*}{ Attributes } & \multicolumn{2}{c}{ Experimental diet } \\
\cline { 2 - 3 } & Starter & Finisher \\
\hline $\mathrm{DM}$ & 878.5 & 874.5 \\
$\mathrm{ASH}$ & 147.8 & 173.6 \\
$\mathrm{CP}$ & 232.6 & 186.8 \\
$\mathrm{EE}$ & 45.2 & 48.2 \\
$\mathrm{CF}$ & 38.1 & 53.95 \\
$\mathrm{NFE}$ & 533.3 & 550.3 \\
$\mathrm{NDF}$ & 309.0 & 349.7 \\
$\mathrm{ADF}$ & 111.8 & 122.2 \\
$\mathrm{Ca}$ & 13.8 & 10.2 \\
$\mathrm{P}$ & 9.9 & 9.2 \\
\hline
\end{tabular}

Table 2: Effect of supplementing different levels of butyric acid on weekly body weight (gm) of broiler chicks

\begin{tabular}{lllllll}
\hline \multirow{2}{*}{ Treatment } & \multicolumn{7}{l}{ Age (weeks) } & & & \\
\cline { 2 - 7 } & $\mathbf{1}$ & $\mathbf{2}$ & $\mathbf{3}$ & $\mathbf{4}$ & $\mathbf{5}$ & $\mathbf{6}$ \\
\hline $\mathrm{T}_{1}$ & $197.33^{\mathrm{a}}$ & $319.40^{\mathrm{a}}$ & $444.68^{\mathrm{a}}$ & $670.57^{\mathrm{a}}$ & $885.35^{\mathrm{a}}$ & $955.51^{\mathrm{a}}$ \\
$\mathrm{T}_{2}$ & $195.31^{\mathrm{b}}$ & $315.26^{\mathrm{b}}$ & $437.28^{\mathrm{b}}$ & $640.15^{\mathrm{b}}$ & $715.73^{\mathrm{b}}$ & $894.77^{\mathrm{b}}$ \\
$\mathrm{T}_{3}$ & $195.68^{\mathrm{b}}$ & $317.97^{\mathrm{c}}$ & $451.46^{\mathrm{c}}$ & $624.91^{\mathrm{c}}$ & $714.55^{\mathrm{b}}$ & $902.82^{\mathrm{c}}$ \\
$\mathrm{T}_{4}$ & $202.82^{\mathrm{c}}$ & $307.26^{\mathrm{d}}$ & $496.77^{\mathrm{d}}$ & $695.95^{\mathrm{d}}$ & $675.04^{\mathrm{c}}$ & $920.20^{\mathrm{d}}$ \\
\hline SEM & 0.33 & 0.23 & 0.32 & 1.17 & 0.38 & 0.50 \\
\hline P value & $<0.01$ & $<0.01$ & $<0.01$ & $<0.01$ & $<0.01$ & $<0.01$ \\
\hline
\end{tabular}

Means bearing different superscript in a column differ significantly $(\mathrm{P}<0.05)$

The weekly feed consumption of Cobb 400 broiler birds is presented in Table 3. Feed consumption was observed 
Table 3: Effect of supplementing different levels of butyric acid on weekly feed consumption (gm) of broiler chicks

\begin{tabular}{llllllll}
\hline \multirow{2}{*}{ Treatment } & \multicolumn{7}{c}{ Age (weeks) } \\
\cline { 2 - 8 } & Initial & $\mathbf{1}$ & $\mathbf{2}$ & $\mathbf{3}$ & $\mathbf{4}$ & $\mathbf{5}$ & $\mathbf{6}$ \\
\hline $\mathrm{T}_{1}$ & 39.29 & $165.55^{\mathrm{a}}$ & $369.53^{\mathrm{a}}$ & $610.37^{\mathrm{a}}$ & $1022.25^{\mathrm{a}}$ & $1378.84^{\mathrm{a}}$ & $1782.37^{\mathrm{a}}$ \\
$\mathrm{T}_{2}$ & 40.13 & $170.35^{\mathrm{b}}$ & $376.91^{\mathrm{b}}$ & $642.17^{\mathrm{b}}$ & $1053.20^{\mathrm{b}}$ & $1445.95^{\mathrm{b}}$ & $1857.77^{\mathrm{b}}$ \\
$\mathrm{T}_{3}$ & 39.64 & $173.60^{\mathrm{c}}$ & $379.87^{\mathrm{c}}$ & $667.80^{\mathrm{c}}$ & $1112.98^{\mathrm{c}}$ & $1498.40^{\mathrm{c}}$ & $1963.20^{\mathrm{c}}$ \\
$\mathrm{T}_{4}$ & 39.46 & $181.40^{\mathrm{d}}$ & $380.42^{\mathrm{c}}$ & $702.35^{\mathrm{d}}$ & $1161.00^{\mathrm{d}}$ & $1577.44^{\mathrm{d}}$ & $2036.04^{\mathrm{d}}$ \\
$\mathbf{S E M}$ & 0.26 & 0.69 & 0.60 & 0.90 & 1.25 & 3.80 & 7.95 \\
P value & 0.12 & $<0.01$ & $<0.01$ & $<0.01$ & $<0.01$ & $<0.01$ & $<0.01$ \\
\hline
\end{tabular}

Means bearing different superscript in a column differ significantly $(\mathrm{P}<0.05)$.

Table 4: Effect of supplementing different levels of butyric acid on weekly feed conversion ratio of broiler chicks

\begin{tabular}{lllllll}
\hline \multirow{2}{*}{ Treatment } & \multicolumn{7}{c}{ Age (weeks) } \\
\cline { 2 - 7 } & $\mathbf{1}$ & $\mathbf{2}$ & $\mathbf{3}$ & $\mathbf{4}$ & $\mathbf{5}$ & $\mathbf{6}$ \\
\hline $\mathrm{T}_{1}$ & $1.56^{\mathrm{a}}$ & $1.56^{\mathrm{a}}$ & $1.84^{\mathrm{a}}$ & $1.62^{\mathrm{a}}$ & $2.50^{\mathrm{a}}$ & $2.38^{\mathrm{a}}$ \\
$\mathrm{T}_{2}$ & $1.50^{\mathrm{b}}$ & $1.52^{\mathrm{b}}$ & $1.64^{\mathrm{b}}$ & $1.55^{\mathrm{b}}$ & $1.83^{\mathrm{b}}$ & $2.22^{\mathrm{b}}$ \\
$\mathrm{T}_{3}$ & $1.46^{\mathrm{c}}$ & $1.54^{\mathrm{ab}}$ & $1.56^{\mathrm{c}}$ & $1.40^{\mathrm{c}}$ & $1.86^{\mathrm{b}}$ & $1.97^{\mathrm{c}}$ \\
$\mathrm{T}_{4}$ & $1.43^{\mathrm{d}}$ & $1.54^{\mathrm{ab}}$ & $1.54^{\mathrm{d}}$ & $1.51^{\mathrm{d}}$ & $1.62^{\mathrm{c}}$ & $2.05^{\mathrm{c}}$ \\
\hline SEM & 0.008 & 0.007 & 0.007 & 0.006 & 0.023 & 0.043 \\
\hline P value & $<0.01$ & $<0.01$ & $<0.01$ & $<0.01$ & $<0.01$ & $<0.01$ \\
\hline
\end{tabular}

Means bearing different superscript in a column differ significantly $(\mathrm{P}<0.05)$.

to increase till $4^{\text {th }}$ weeks after that it remained static. Feed consumption was found to differ significantly between the groups from $1^{\text {st }}$ to $6^{\text {th }}$ week. Weekly feed consumption was found to increase significantly in $0.5 \%, 1.0 \%$ and $1.5 \%$ supplemented groups on $2^{\text {nd }}, 3^{\text {rd }}, 4^{\text {th }}$ and $6^{\text {th }}$ week whereas in $1^{\text {st }}$ week $1.5 \%$ supplemented groups was found higher than control. Adil et al. (2010) also indicated that the organic acid supplementation, irrespective of type and level of acid used, had a beneficial effect on the feed consumption of broiler chickens. Banday et al. (2015) found non-significant effect on cumulative feed consumption in the birds. But Al-Kassi and Mohssen (2009)reported significantly higher average daily feed consumptionin broiler supplemented with formic and propionic acids compared with the control group.

The feed conversion ratio of broiler birds (Table 4) of all the four groups measured at weekly interval is presented as FCR was found to increase up to last $6^{\text {th }}$ week which means feed efficiency decreased with increasing time period. The highest FCR were represented in $T_{1}$ control group which was followed by $\mathrm{T}_{2}, \mathrm{~T}_{3}$ and $\mathrm{T}_{4}$ supplemented groups. The feed conversion ratio of Cobb 400 birds during different period of growth of all the four groups presented in table 5 .

Table 5: Effect of supplementing different levels of butyric acid on feed conversion ratio of broiler chicks

\begin{tabular}{llll}
\hline \multirow{2}{*}{ Treatment } & \multicolumn{3}{c}{ Age (weeks) } \\
\cline { 2 - 4 } & FCR (Starter) & FCR (Finisher) & FCR (Total) \\
\hline $\mathrm{T}_{1}$ & $1.66^{\mathrm{a}}$ & $2.42^{\mathrm{a}}$ & $1.99^{\mathrm{a}}$ \\
$\mathrm{T}_{2}$ & $1.56^{\mathrm{b}}$ & $2.01^{\mathrm{b}}$ & $1.76^{\mathrm{b}}$ \\
$\mathrm{T}_{3}$ & $1.48^{\mathrm{c}}$ & $1.90^{\mathrm{c}}$ & $1.66^{\mathrm{c}}$ \\
$\mathrm{T}_{4}$ & $1.51^{\mathrm{d}}$ & $1.83^{\mathrm{d}}$ & $1.65^{\mathrm{c}}$ \\
SEM & 0.002 & 0.019 & 0.007 \\
P value & $<0.01$ & $<0.01$ & $<0.01$ \\
\hline
\end{tabular}

Means bearing different superscript in a column differ significantly $(\mathrm{P}<0.05)$.

FCR was found higher in finisher phase in compression to starter phase which means feed efficiency decreased with increasing time period. $1.0 \%$ and $1.5 \%$ supplemented 
Table 6: Carcass quality characteristics of broiler birds at 6 weeks of age fed with different levels of butyric acid

\begin{tabular}{llllllllll}
\hline Treatment & $\begin{array}{l}\text { Pre fasting } \\
\text { weight }(\mathbf{g m})\end{array}$ & $\begin{array}{l}\text { Post fasting } \\
\text { weight }(\mathbf{g m})\end{array}$ & $\begin{array}{l}\text { Shrinkage } \\
(\%)\end{array}$ & $\begin{array}{l}\text { Dressing } \\
\text { yield }(\mathbf{g m})\end{array}$ & $\begin{array}{l}\text { Dressing } \\
\text { yield }(\%)\end{array}$ & $\begin{array}{l}\text { Eviscerated } \\
\text { yield }(\mathbf{g m})\end{array}$ & $\begin{array}{l}\text { Eviscerated } \\
\text { yield }(\%)\end{array}$ & $\begin{array}{l}\text { Ready to } \\
\text { cook yield } \\
(\mathbf{g m})\end{array}$ & $\begin{array}{l}\text { Ready to } \\
\text { cook yield } \\
(\%)\end{array}$ \\
\hline $\mathrm{T}_{1}$ & $1783.00^{\mathrm{a}}$ & $1675.75^{\mathrm{a}}$ & 6.01 & $1182.50^{\mathrm{a}}$ & 70.56 & $888.16^{\mathrm{a}}$ & $53.00^{\mathrm{a}}$ & $971.13^{\mathrm{a}}$ & $57.95^{\mathrm{a}}$ \\
$\mathrm{T}_{2}$ & $1856.00^{\mathrm{b}}$ & $1745.50^{\mathrm{b}}$ & 5.95 & $1248.75^{\mathrm{b}}$ & 71.54 & $955.63^{\mathrm{b}}$ & $54.75^{\mathrm{ab}}$ & $1042.97^{\mathrm{b}}$ & $59.75^{\mathrm{a}}$ \\
$\mathrm{T}_{3}$ & $1963.25^{\mathrm{c}}$ & $1846.50^{\mathrm{c}}$ & 5.94 & $1302.25^{\mathrm{c}}$ & 70.52 & $1024.78^{\mathrm{c}}$ & $55.50^{\mathrm{b}}$ & $1119.76^{\mathrm{c}}$ & $60.64^{\mathrm{b}}$ \\
$\mathrm{T}_{4}$ & $2036.25^{\mathrm{d}}$ & $1914.25^{\mathrm{d}}$ & 5.99 & $1334.75^{\mathrm{c}}$ & 69.72 & $1081.58^{\mathrm{d}}$ & $56.50^{\mathrm{b}}$ & $1181.43^{\mathrm{d}}$ & $61.71^{\mathrm{b}}$ \\
\hline SEM & 0.930 & 1.753 & 0.05 & 9.656 & 0.523 & 10.213 & 0.554 & 10.176 & 0.554 \\
\hline Pvalue & $<0.01$ & $<0.01$ & 0.80 & $<0.01$ & $<0.01$ & $<0.01$ & $<0.01$ & $<0.01$ & $<0.01$ \\
\hline
\end{tabular}

Means bearing different superscript in a column differ significantly $(\mathrm{P}<0.05)$.

Table 7: Cut-up parts of broiler birds at 6 weeks of age fed with different levels of butyric acid

\begin{tabular}{lllllll}
\hline Treatment & Thigh (\%) & Drum stick (\%) & Breast (\%) & Back (\%) & Neck (\%) & Wing (\%) \\
\hline $\mathrm{T}_{1}$ & 18.01 & 18.01 & $19.79^{\mathrm{a}}$ & 23.35 & 6.86 & 13.63 \\
$\mathrm{~T}_{2}$ & 17.89 & 17.89 & $19.37^{\mathrm{a}}$ & 23.30 & 7.10 & 13.56 \\
$\mathrm{~T}_{3}$ & 18.86 & 18.86 & $18.03^{\mathrm{b}}$ & 22.64 & 7.20 & 13.59 \\
$\mathrm{~T}_{4}$ & 18.72 & 18.72 & $18.13^{\mathrm{b}}$ & 22.74 & 7.32 & 13.48 \\
\hline SEM & 0.25 & 0.27 & 0.22 & 0.27 & 0.12 & 0.11 \\
\hline P value & 0.87 & 0.39 & $<0.01$ & 0.09 & 0.08 & 0.88 \\
\hline
\end{tabular}

Means bearing different superscript in a column differ significantly $(\mathrm{P}<0.05)$.

groups were found efficient than control in finisher and total FCR. Adil et al. (2011) also found that the birds fed diets supplemented with organic acids showed significantly higher feed conversion ratio. Panda et al. (2009) also observed graded levels of $0.4 \%$ butyric acid improved feed conversion ratio in broiler. On contrary, Mohamed et al. (2018) found no effect of different levels of organic mixture on feed conversion ratio of broiler chickens.

\section{Carcass characteristics}

The effect of different levels Butyric acid supplemented on carcass characteristic of Cobb 400 broilers is presented in table 6. Carcass quality parameters were found similar in all experiment groups and found to differ significantly between groups. Pre fasting weight (gm) and post fasting weight (gm) were found to be highest in $\mathrm{T}_{4}$ supplemented group than control but shrinkage (\%), dressing yield (gm) and dressing yield (\%) were observed to be highest in $\mathrm{T}_{1}$ Control group than other supplemented groups i.e. $\mathrm{T}_{2}$, $\mathrm{T}_{3}, \mathrm{~T}_{4}$. The eviscerated yield (gm) and eviscerated yield
(\%) were represented to highest in $\mathrm{T}_{4}$ supplemented group whereas ready to cook yield (gm) and ready to cook yield (\%) is also highest in $\mathrm{T}_{4}$ supplemented group than control. The cut-up parts of Cobb 400 broilers (Table 7) is presented as thigh (\%), drum stick (\%), neck (\%) and wing $(\%)$ were found similar in all the experimental groups whereas the breast (\%) was observed lower in $\mathrm{T}_{3}$ and $\mathrm{T}_{4}$ supplemented groups than other. In table 8 the following parameters are heart $(\%)$, liver $(\%)$, gizzard $(\%)$ and spleen $(\%)$ were observed. Heart (\%) is lowest in $\mathrm{T}_{4}$ than control whereas heart $(\%)$ and liver (\%) differ significantly in all treatment groups. But heart (\%) and gizzard (\%) is highest in $\mathrm{T}_{1}$ group than supplemented group. The liver ( $\%$ ) was observed to be highest in $\mathrm{T}_{2}$ whereas spleen (\%) in $\mathrm{T}_{4}$ supplemented group than control.

The effect of different levels supplemented on digestive organ of broilers (Table 9) is presented. Digestive organ except proventricular (\%) and cecal length (\%) were found differ significantly in all experiment groups whereas cecal length (\%) was found lower in $\mathrm{T}_{3}$ group than control. The proventricular $(\%)$, cecal length $(\mathrm{cm})$ and cecal length 
Table 8: Gizzard, spleen, liver and heart of broiler birds at 6 weeks of age fed with different levels of butyric acid

\begin{tabular}{lllll}
\hline Treatment & Heart (\%) & Liver (\%) & Gizzard (\%) & Spleen (\%) \\
\hline $\mathrm{T}_{1}$ & $0.65^{\mathrm{a}}$ & $2.11^{\mathrm{a}}$ & $2.18^{\mathrm{a}}$ & $0.09^{\mathrm{a}}$ \\
$\mathrm{T}_{2}$ & $0.60^{\mathrm{b}}$ & $2.28^{\mathrm{b}}$ & $2.11^{\mathrm{b}}$ & $0.10^{\mathrm{a}}$ \\
$\mathrm{T}_{3}$ & $0.56^{\mathrm{c}}$ & $2.53^{\mathrm{c}}$ & $2.04^{\mathrm{c}}$ & $0.11^{\mathrm{a}}$ \\
$\mathrm{T}_{4}$ & $0.54^{\mathrm{d}}$ & $2.67^{\mathrm{d}}$ & $2.00^{\mathrm{c}}$ & $0.15^{\mathrm{b}}$ \\
\hline SEM & 0.003 & 0.028 & 0.011 & 0.004 \\
\hline P value & $<0.01$ & $<0.01$ & $<0.01$ & $<0.01$ \\
\hline
\end{tabular}

Means bearing different superscript in a column differ significantly $(\mathrm{P}<0.05)$.

Table 9: Development of digestive organ of broiler birds at 6 weeks of age fed with different levels of butyric acid

\begin{tabular}{lllllcc}
\hline Treatment & $\begin{array}{l}\text { Proventricular } \\
\text { weight }(\%)\end{array}$ & $\begin{array}{l}\text { Cecal length } \\
(\mathbf{c m})\end{array}$ & $\begin{array}{l}\text { Cecal length } \\
(\%)\end{array}$ & $\begin{array}{l}\text { Small intestine } \\
(\%)\end{array}$ & $\begin{array}{l}\text { Small intestine } \\
\text { length }(\%)\end{array}$ & $\begin{array}{l}\text { Large intestine } \\
(\%)\end{array}$ \\
\hline $\mathrm{T} 1$ & $0.49^{\mathrm{a}}$ & $11.83^{\mathrm{a}}$ & $0.70^{\mathrm{a}}$ & $3.68^{\mathrm{a}}$ & $8.28^{\mathrm{a}}$ & $0.17^{\mathrm{a}}$ \\
$\mathrm{T} 2$ & $0.48^{\mathrm{ab}}$ & $11.57^{\mathrm{b}}$ & $0.66^{\mathrm{b}}$ & $3.88^{\mathrm{b}}$ & $9.00^{\mathrm{ab}}$ & $0.22^{\mathrm{b}}$ \\
$\mathrm{T} 3$ & $0.47^{\mathrm{ab}}$ & $11.23^{\mathrm{c}}$ & $0.60^{\mathrm{c}}$ & $4.17^{\mathrm{c}}$ & $9.45^{\mathrm{bc}}$ & $0.25^{\mathrm{c}}$ \\
$\mathrm{T} 4$ & $0.47^{\mathrm{b}}$ & $10.83^{\mathrm{d}}$ & $0.56^{\mathrm{d}}$ & $4.53^{\mathrm{d}}$ & $9.71^{\mathrm{c}}$ & $0.27^{\mathrm{c}}$ \\
\hline SEM & 0.004 & 0.054 & 0.003 & 0.086 & 0.092 & 0.010 \\
\hline P value & 0.01 & $<0.01$ & $<0.01$ & $<0.01$ & $<0.01$ & $<0.01$ \\
\hline
\end{tabular}

Means bearing different superscript in a column differ significantly $(\mathrm{P}<0.05)$.

(\%) were found to be highest in $T_{1}$ Control group than supplemented groups but small intestine (\%), small intestine length (\%) and large intestine (\%) were observed to highest in $\mathrm{T}_{4}$ supplemented group than control. Mishra et al. (2013) suggested that formic acid supplementation at a dose rate of $1.5 \%$ as well as $2 \%$ in the diet of broiler chickens is advantageous to obtain improved carcass yield. Ramigani et al. (2017) investigated the carcass traits of broilers fed with different organic acid combination supplemented diets. Result revealed no significant difference of the organic acid supplementation in the ready- to- cook yields among the groups, but significantly increased giblet yields on \% live weight basis. Jang (2011) found that addition of achillea and butyric acid improved percent of liver and breast in experimental broiler birds. Adil et al. (2011) indicated no effect on carcass characteristics among all treatments when supplemented with organic acids to broiler chicken. Islam et al. (2008) conducted an experiment with commercial broilers to investigate the effects of feeding citric acid, acetic acid and their combination on their performance. Carcass characteristics were not affected by dietary treatments.
While Panda et al. (2009) showed that carcass yield was higher significantly in all the butyrate treatment groups compared to the control or antibiotic group.

\section{CONCLUSION}

It can be concluded that supplementation of butyric acid addition at the level of $1.5 \%$ in broiler diet improve body weight, feed consumption, feed conversion ratio, carcass characteristics and also slaughter traits.

\section{ACKNOWLEDGEMENTS}

The authors are thankful to Vice Chancellor SVPUAT, Meerut for providing necessary facilities to conduct the research work.

\section{REFERENCES}

Adil, S., Banday, T., Bhat, G.A., Salahuddin, M., Raquib, M. and Shanaz, S. 2011. Response of broiler chicken to dietary supplementation of organic acids. J. Cent. Eur. Agric., 12: 498-508. 
Adil, S., Tufail, B., Gulam, A.B., Masood, S. and Manzoor, R. 2010. Effect of dietary supplementation of organic acids on performance, intestinal histomorphology and serum biochemistry of broiler chicken. Vet. Med. Int., 12: 1-7.

Aghazadeh, A.M. and Yazdi, M.T. 2012. Effect of butyric acid supplementation and whole wheat inclusion on the performance and carcass traits of broilers. S. Afr. J. Anim. Sci., 42: 241-248.

AOAC. 2005. Official methods of analysis. Association of official analytical chemists. $18^{\text {th }}$ edition. Washington D.C.

Banday, M.T., Adil, S., Khan, A.A. and Untoo, M. 2015. A study on efficacy of fumaric acid supplementation in diet of broiler chicken. Int. J. Poult. Sci., 14: 589-594.

BIS. 1992. Indian Standard, Poultry Feeds Specifications. BIS., $4^{\text {th }}$ Review. Manak Bhawan, 9, Bahadur Shah Zafar Marg, New Delhi, India.

Galib Al-Kassi, A. and Aqeel Mohseen, M. 2009. Comparative study between single organic acid effect and synergistic organic acid effect on broiler performance. Pak. J. Nutr., 8: 896-899.

Ghazalah, A.A., Atta, A.M., Elkloub, K., Mustafa, M.E.L. and Shata, R.F.H. 2011. Effect of dietary supplementation of organic acids on performance, nutrients digestibility and health of broiler chicks. Int. J. Poult. Sci., 10: 176-184.

Huyghebaert, G., Richard, D. and Van Immerseel, F. 2011. An update on alternatives to antimicrobial growth promoters for broilers. Vet. J., 187: 182-188.

Imran, M., Ahmed, S., Dittal, Y.A., Mehmood, S., Rasool, S. and Zia, M.W. 2018. Effects of microencapsulated butyric acid supplementation on growth performance and ileal digestibility of protein, gut health and immunity in broilers. Indian J. Anim. Res., 52: 1618-1622.
Islam, M.Z., Khandakerl, Z.H., Chowdhury, S.D. and Islam, K.M.S. 2008. Effect of citric acid and acetic acid on the performance of broilers. J. Bangladesh Agric. Univ., 6: 315320.

Jang, J.P. 2011. Comparative effect of achillea and butyric acid on performance, carcass traits and serum composition of broiler chickens. Ann. Biol. Res., 2: 469-473.

Mishra, A., Ray, S., Sarkar, S.K. and Haldar, S. 2013. Effects of formic acid supplementation at incremental levels of growth performance and carcass traits of broiler chickens. Int. J. Sci. Res., 2: 11.

Mohamed, A.A., Habib, A.B., Elterfi, A.M.E., Shulukh, E.S.A., Abubaker, A.A., Abdelwahid, H.H., Basheer, E.O. and Hassouna, S.M. 2018. Effect of dietary supplementation of increasing levels of organic acid mixture on performance and carcass characteristics of broiler chickens. IOSR. J. Agri. Vet. Sci., 11: 2319-2372.

Panda, A.K., Rao, S.R., Raju, M.V.L.N. and Sunder, G.S. 2009. Effect of butyric acid on performance, gastrointestinal tract health and carcass characteristics in broiler chickens. AsianAustralas. J. Anim. Sci., 22: 1026-1031.

Ramigani, V.R., Ramana, J.V., Rao, D.S. and Shakila, S. 2017. Effect of dietary supplementation of organic acids in combination on performance and carcass traits of broiler chicken. Anim. Nutr. Technol., 17: 181.

Sarkar, P.K., Chowdhury, S.D. and Kabir, M.H. 2008. Comparative study on the productivity and profitability of commercial broiler, cockerel of a layer strain and cross bred chicks. Bang. J. Anim. Sci., 37: 89-98.

Snedecor, G.W. and Cochran, W.G. 1994. Statistical methods. $9^{\text {th }}$ edition. The Iowa, state university press, Ames, Iowa.

SPSS. 2011. Statistics version 20.0. IBM SPSS Inc., USA. 
